\title{
The conservation of loggerhead turtles in Zakynthos, Greece
}

\author{
Lynda M. Warren and Eleni Antonopoulou
}

The population of loggerhead turtles Caretta caretta nesting on the island of Zakynthos, Greece, the largest known rookery in the Mediterranean, is in danger of dying out because of the effects of human interference. Tourism is a prime factor in causing problems, which include direct disturbance of nesting females, compaction of the sand and obstruction of access, photic pollution affecting the hatchlings and accidental damage to adults from speed boats. Attempts are being made to conserve the turtles, and a recent Ministerial Decision should be of help, but implementation of conservation measures is difficult to achieve. This is because the local economy is highly dependent on the tourist industry and there is an understandable reluctance to see this curtailed in any way just to protect the turtles.

The loggerhead turtle has a widespread, but patchy, distribution in sub-tropical and temperate areas (Sternberg, 1981). It is very difficult to estimate population numbers for a species that spends so much of its time at sea, but it is certain that populations in the Mediterranean are declining (Sutherland, 1984). In Israel, for example, where there were 15 nests every kilometre in the 1950 s, there were only two nests in $250 \mathrm{~km}$ of shore in 1979 (Sella, 1983). The reasons for population declines, however, are not always clear. Ruckdeschel and Zug (1982), for example, noted an increase in the numbers of strandings of loggerhead turtles in Georgia, USA, but were unable to account for these, other than to generally point the finger towards human interference. There is, in fact, considerable cause for alarm over the effect of human activities on turtles.

Greater affluence in western countries has resulted in an increase in tourism in previously undeveloped holiday resorts with an inevitable loss of wildlife habitat. Apart from the direct effect of building works, further damage may arise from the activities of the tourist eager to explore the natural habitats and see the wildlife. Even the most conservation-minded visitors can cause problems when they are in large numbers. The plight of the loggerhead turtle population nesting on
Zakynthos (Figure 1), one of the Ionian islands of Greece, is a case in point. The population was probably never very large in world terms and has recently been severely affected by human interference, resulting from an increase in tourism. The main thrust for conservation originated with a visiting Greek holiday-maker and has since involved several voluntary organizations, both national and international, which have undertaken basic research and

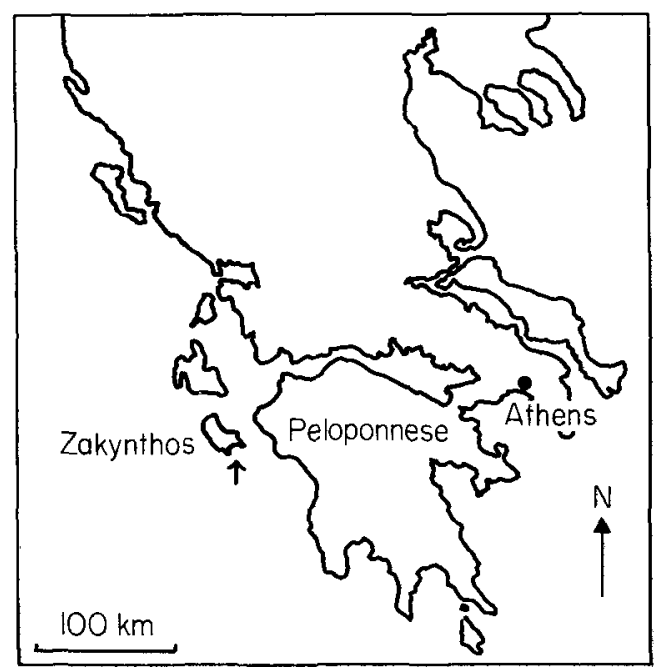

Figure 1. Sketch map to show the location of Zakynthos in relation to the Greek mainland. Laganas Bay is indicated by an arrow. 
lobbied the Greek authorities to instigate protective measures. This paper reports the history of the attempts to conserve these turtles and shows from first hand experience why progress is often slower than hoped for.

\section{Nesting beaches}

Sightings of loggerhead turtles in Greek waters were recorded by Mertens and Wermuth in 1960 , but there was very little documentation of their nesting on the Greek coast until Margaritoulis (1982) made observations on their nesting activity on Zakynthos. At that time there were no reliable data for population numbers on the island but Sutherland (1984) gives a figure of 2640 nests in 1983. The main nesting area is in Laganas Bay (Figure 2), in which there are several favoured nesting beaches. All are sandy, but they differ in the quality of the sand, the amount of vegetation and, perhaps most importantly, in the degree of tourist development (see Table 1). The majority of the nests are made on Sekania, an isolated beach with no human habitation within several kilometres. Most of the other sites suffer from some human interference. The largest beach, Lagana, for example, is heavily developed and, although turtles do nest at the less developed eastern end, numbers are low, amounting to less than a fifth of those on Sekania, which is much smaller (Sutherland, 1984).

\section{Factors affecting nesting success}

The actual process of nesting has been well documented (Bustard, 1972), although precise details of the conditions necessary for its success are still unknown. The nesting season

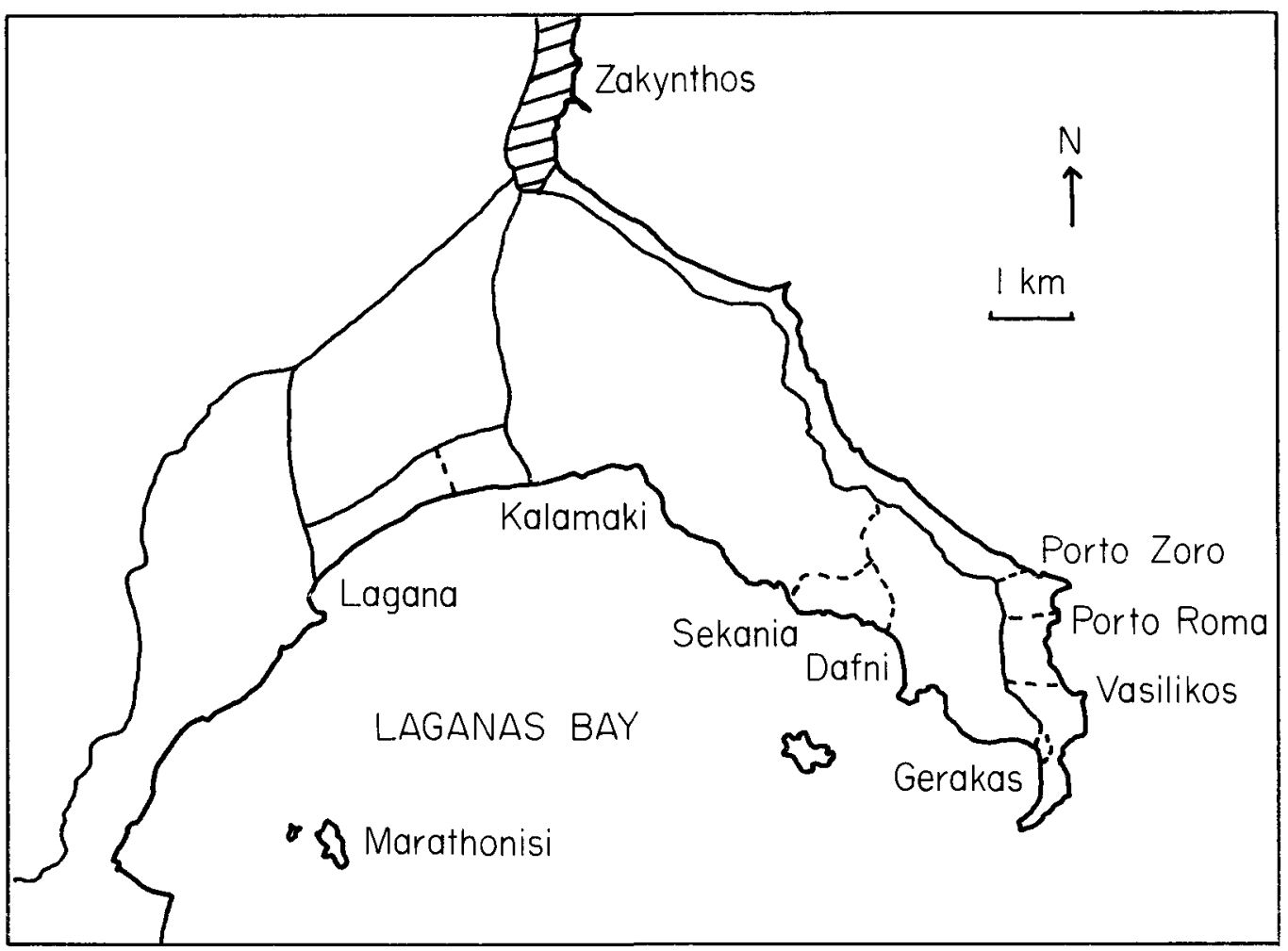

Figure 2. Sketch map of Laganas Bay showing nesting beaches and access.

Metalled roads

Dirt roads and tracks .-_-_-_--. 
in Zakynthos is from June to August (unfortunately coincident with the tourist season) during which time an individual female lays, on average, three clutches. Nesting always takes place at night. The female hauls herself up the beach, then scrapes out a shallow depression and a deeper nest hole in which she deposits approximately 150 eggs, which she then covers before she returns to the sea. After approximately 50-60 days the young hatch and, again at night or in the early morning, make their way down to the sea. The sex of turtles is determined by the incubation temperature of the eggs and it is clear that not just any sand on any beach will do. We do not know, however, what the precise requirements are. The sand must clearly be of the right range of grain sizes. If it is too coarse it will not hold moisture so the eggs will desiccate; if it is too fine it will be impossible for the female to scrape a depression. It also appears that organic content may be important because it may cause an increase in temperature. Analyses of sand taken from Lagana and Kalamaki are given in Table 2. In each case it consists mainly of fine grains with an unexpectedly high organic content.

Regardless of the effects of natural factors such as these, it is clear from conversations with local people that the population of turtles has declined and changed its distribution and

Table 1. Turtle nesting beaches in Zakynthos

\begin{tabular}{|c|c|c|c|c|}
\hline Beach & Access & Habitation & Features & Nesting \\
\hline Lagana & $\begin{array}{l}9 \text { km from } \\
\text { capital; } \\
\text { good road }\end{array}$ & $\begin{array}{l}\text { Mostly developed; } \\
\text { beach used as } \\
\text { a road }\end{array}$ & Fine sand & $\begin{array}{l}\text { Once the most } \\
\text { popular beach, } \\
\text { now only at } \\
\text { eastern end }\end{array}$ \\
\hline Kalamaki & $\begin{array}{l}7 \mathrm{~km} \text { from } \\
\text { capital; } \\
\text { good road }\end{array}$ & $\begin{array}{l}\text { Large hotel; } \\
\text { boats on beach }\end{array}$ & $\begin{array}{l}\text { Fine sand; } \\
\text { some pebbles }\end{array}$ & $\begin{array}{l}\text { Successful at } \\
\text { eastern end } \\
\text { away from hotel }\end{array}$ \\
\hline Sekania & Track/path & None & $\begin{array}{l}\text { Fine sand } \\
\text { with pebbles }\end{array}$ & $\begin{array}{l}\text { Most important } \\
\text { nesting beach; } \\
\text { recent increase } \\
\text { in numbers - } \\
\text { ? from Lagana }\end{array}$ \\
\hline Dafni & $\begin{array}{l}\text { Track; access } \\
\text { mainly from } \\
\text { sea }\end{array}$ & $\begin{array}{l}\text { Small taverna; } \\
\text { camp site }\end{array}$ & $\begin{array}{l}\text { Sand; many } \\
\text { pebbles; trees } \\
\text { act as natural } \\
\text { screen }\end{array}$ & Some nests \\
\hline Gerakas & Dirt road & $\begin{array}{l}\text { Taverna; camp } \\
\text { site; boats on } \\
\text { beach }\end{array}$ & Fine sand & Some nests \\
\hline Marathonisi & $\begin{array}{l}\text { Island; } \\
\text { by sea }\end{array}$ & Uninhabited & $\begin{array}{l}\text { Very coarse } \\
\text { sand }\end{array}$ & Some nests \\
\hline Porto Zoro & $\begin{array}{l}\text { Dirt road } \\
\text { since } 1960\end{array}$ & Taverna & Not known & $\begin{array}{l}\text { ? Some evidence } \\
\text { of nesting }\end{array}$ \\
\hline Porto Roma & $\begin{array}{l}\text { Dirt road } \\
\text { since } 1960\end{array}$ & Taverna & Not known & Once used \\
\hline Vasilikos & $\begin{array}{l}\text { Dirt road } \\
\text { since } 1960\end{array}$ & Taverna & Not known & Once used \\
\hline
\end{tabular}


Table 2. Qualitative analysis of sand from Lagana and Kalamaki

\begin{tabular}{lll}
\hline & Lagana & Kalamaki \\
\hline $\begin{array}{l}\text { Median grain } \\
\text { size (mm) }\end{array}$ & $\begin{array}{l}0.200 \\
\text { (fine sand) }\end{array}$ & $\begin{array}{l}0.210 \\
\text { (fine sand) }\end{array}$ \\
$\begin{array}{l}\text { Size range of } \\
\text { median 50\% } \\
\text { of grains (mm) }\end{array}$ & $0.160-0.225$ & $0.180-0.230$ \\
Organic content & $9.2 \%$ & $8.3 \%$ \\
\hline
\end{tabular}

Analyses were carried out according to Holme and McIntyre (1971).

behaviour since tourism started in the 1970s. Several people can remember the turtles nesting on Lagana in places now devoid of nests. Indeed, the Lagana/Kalamaki stretch was probably the original preferred site and the relatively large population now on Sekania may include females no longer using these beaches.

\section{The effects of tourism}

There are several reasons why tourism causes problems for turtles. Firstly, there is the direct effect of disturbance during the nesting process. Several holiday firms have used the presence of the turtles as an attraction for tourists who, therefore, want to see them when they arrive in Zakynthos. As they are only really evident while nesting this means that tourists have been visiting the beaches at night with torches. Tourists often try to get too near to the animals, which are frightened and abandon their nesting attempt.

Even where nesting is successfully achieved the problems are not over. Hatchlings are very vulnerable to predators such as gulls, martens and rats. Although in some cases hatchling predation is a major cause of mortality (for example in Florida where racoons are the culprits (Richardson and Richardson, 1983)) it does not seem to be of great significance on Zakynthos beaches. Indeed, Sutherland (1984) even suggests that tourists may improve the situation by keeping gulls away.
Nevertheless, the passage of the hatchling down the shore to the sea is potentially one of the most dangerous stages in the life history, and behavioural traits have evolved that serve to minimize the period of exposure. Considerable work has been carried out on the ways in which young turtles orientate themselves and this has been summarized by Carr and Ogren (1960). It is believed that loggerheads are guided by phototaxis and photokinesis, in other words they are attracted towards light and will move faster under bright conditions. More specifically, they are attracted by a bright surf and repelled by a broken horizon and dark patterns. They are also positively geotropic, which will tend to make them move downshore. But the most important factor is probably the attraction towards light. Indeed, on dark cloudy nights the orientation capacity is diminished. If an otherwise dark night is broken by street lights or lights on a taverna, the turtles are attracted towards these lights in completely the wrong direction. An example of just how devastating this can be is given by McFarlane (1963). He found that the combined effect of a bright sky, caused by the general lights of a heavily populated area in southern Florida, coupled with the direct effect of street lights $45 \mathrm{~m}$ behind the beach, resulted in 90 out of 115 hatchlings being run over by cars. Only six hatchlings moved directly seawards, although some changed direction after an initial movement upshore. This is an extreme example as the beach was backed by a major highway, but it does bring home just how disastrous such photic disturbance can be. Sutherland (1984) records that hatchlings on Lagana and Kalamaki displayed erratic behaviour and moved away from the sea or turned around in circles.

On beaches particularly popular with tourists compaction of the sand by trampling or by vehicles may preclude successful emergence of the hatchlings (Mann, 1977). In time this will render a beach totally unsuitable for the turtles, as seems to have happened on the western part of Lagana beach.

A further problem affecting both adults and hatchlings is the presence of obstructions on the beach. Pedal-boats are operated from some 
of the beaches, for example, and are left on the beach overnight. Vegetation can also be a problem, as at Lagana where tamarisk trees have been planted on the beach. Although there is no problem at present, with time their roots will consolidate the sand and hinder digging by the females. In contrast trees can be beneficial if planted higher up the beach, as at Dafni, where they create a natural barrier shielding the turtles from the lights of the taverna.

\section{Conservation measures}

In 1977 Dimitrios Margaritoulis, a scientist on vacation in Zakynthos, became concerned about the turtles. He embarked on a scientific study and recorded numbers of adults, eggs and hatchlings. He also drew the attention of the National Council for Physical Planning and the Environment (NCPPE) and the Hellenic Society for the Protection of Nature to the presence of the turtles and urged them to take action to protect them. In 1980 Greece became a member of the EEC and formed a new Department of the Environment. During that year two Presidential Directives were issued declaring that the loggerhead turtle was vulnerable and rare and prohibiting fishing or the taking of eggs. By the summer of 1980 a conservation programme had been set up by the NCPPE and the Programme for the Control of Pollution in the area of Athens, and adult females were tagged in an attempt to estimate population numbers and breeding patterns. Because of a change in government the NCPPE folded in 1981, but work continued under the auspices of the newly created Sea Turtle Protection Society (STPS). In 1982 the Department of the Environment put before Parliament a paper concerned with controlling photic pollution linked with coastal development. This paper was never passed, although it was submitted on several occasions. A Ministerial Decision did, however, come into force in 1982. This nominally prevented all building work in areas of importance for nesting as designated in the proposal and was renewable on a 6-monthly basis. By 1983 the nesting population at Sekania was being regu- larly monitored and other international conservation bodies were involved. It was during this summer that one of us (EA) visited Zakynthos for the first time. Discussions were held with local people and it was possible to see the monitoring programme in action. Visits to the Ministry of the Environment in Athens were also made.

\section{The current situation}

The IUCN Red Data Book (Groombridge, 1982) classifies the loggerhead turtle as vulnerable and makes special mention of the Zakynthos population as likely to become endangered. In 1984 Sutherland was able to conclude from his estimates that the population still had the potential to survive and increase in numbers provided any decline could be halted. Unfortunately this does not seem to have happened and 1987 was regarded by conservationists as something of a critical year for the turtles (Langton, 1987). Considerable pressure, including a threat to organize a tourist boycott, was put on the Greek Government to take action. A new Ministerial Decision was passed early in 1987 based on very similar lines to the 1982 paper. It is basically a plan for development, but does contain some provision designed to protect the turtles. It controls building regulations in the Laganas Bay and divides the area into zones (Figure 3 ). In the most heavily protected nesting areas it is prohibited to build, plant trees or to drive on the beach. The government has plans to expropriate all land in zone I. Provisions for zones IV and IVa, including Kalamaki village, however, aim at developing these areas for tourism. On the tourist front WWF-UK persuaded four of the biggest British tour operators ( 80 per cent of tourists come from Britain) to distribute a leaflet explaining the plight of the turtles to all holiday makers going to Zakynthos. The STPS has set up an information tent on the beach to reinforce the message.

Two further threats have materialized since the early 1980s. In 1983 it was noted that some adult females had damaged carapaces. This 
was put down to accidents with speedboats, but was not thought to be a significant problem. The incidence of such damage has, however, risen with an increase in the number of speedboats in the bay. In 1986 the Ministry of Merchant Marine actually increased the number of licences for speedboats but, following considerable pressure from the Ministry of the Environment, instructed that no more licences were to be given. A Ministerial Decision was agreed as a compromise, restricting the access of speedboats in Laganas Bay for the next 2 years. This will afford protection to the nesting beaches at Dafni and Sekania because they will no longer be accessible, but will do little to tackle the problem of damage to adults at sea. The Ministry of the Environment is believed to be seeking closure of the whole bay to speedboats.

The second new threat is from fisheries interests. Proposals for fish farms, funded in part by the European Community, have been made for a number of places in the Mediterranean, including Laganas Bay. If such

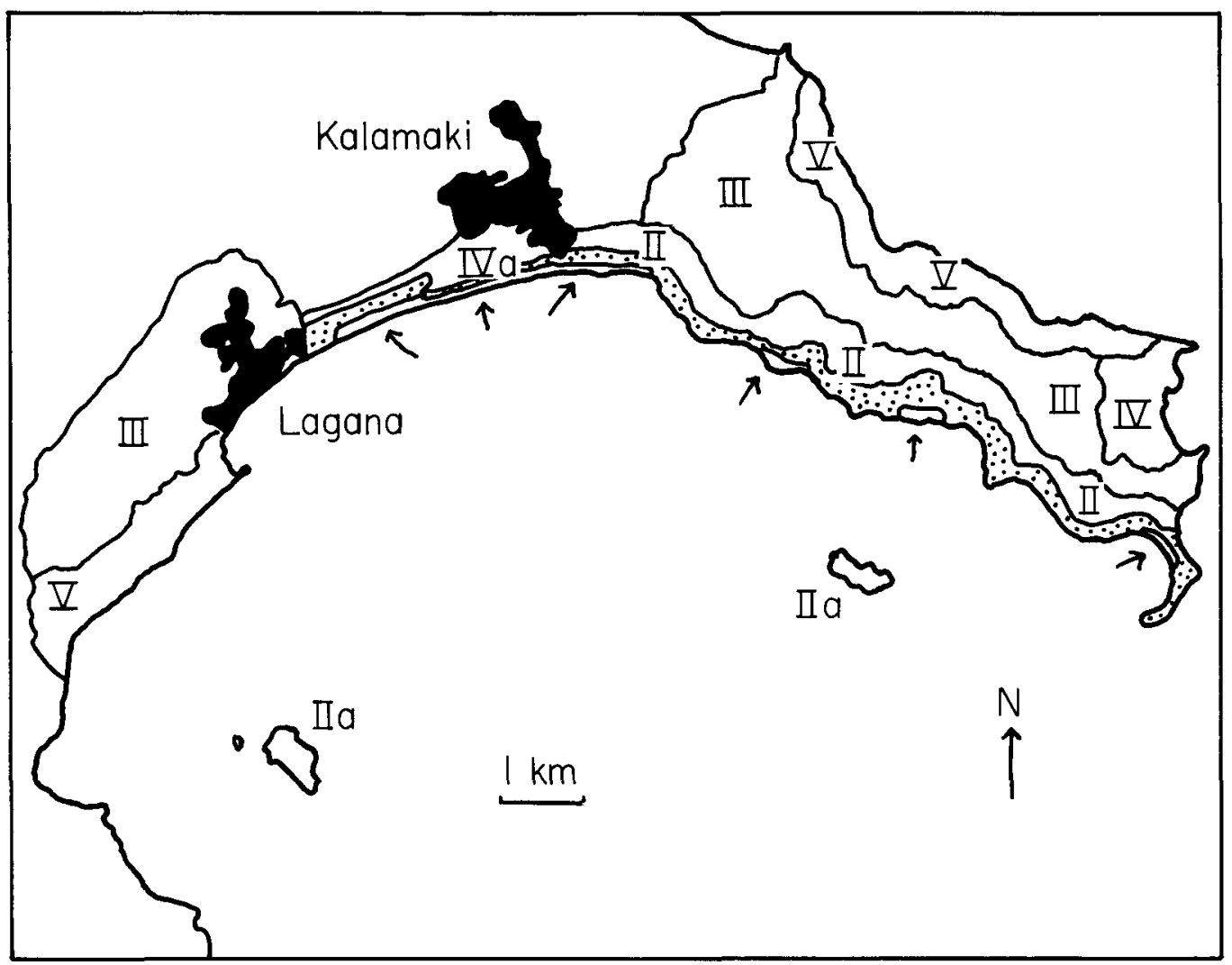

Figure 3. Sketch map of Laganas Bay showing zones declared in the 1987 Ministerial Decision.

Nesting areas: unshaded on the map and indicated by arrows. Beaches to be closed at night. No boats, stalls or trees allowed; sunshades restricted to lower shore. No motor vehicles.

Zone I: Stippled on map. Area of greatest restrictions. Residential buildings of $60 \mathrm{sq} \mathrm{m}$ on 4 ha plots permitted. Zone II: Residential buildings permitted at $120 \mathrm{sq} \mathrm{m}$ per $2 \mathrm{ha}$.

Zone Ila: The islands - only one house permitted on each.

Zone III: Land for cultivation or forestry. No hotels to be built.

Zone IV: Protected forest area. Controlled development allowed.

Zone IVa: Development area with special restrictions concerning light and noise. 15 beds per ha permitted. Zone V: Tourism development areas. The villages of Kalamaki and Lagana are both scheduled for extensive development. 
a farm were to be constructed it could be a hazardous obstruction to the turtles, which might become caught in the cages. Although the original plans have been dropped, the rapid growth of the fish farming industry in Europe may lead to other proposals being made in the future. Dynamite fishing poses a further hazard to the turtles but, apart from these threats, fishing is not a major problem. Most fishing activity takes place outside the nesting season and the Ministry of Agriculture has powers to exclude fishing from near the beaches.

\section{Discussion}

The amount of effort put into the conservation of the turtles of Zakynthos this decade by voluntary bodies of several countries and more recently by the Greek authorities should have ensured successful conservation. Some progress has been made but it has been painfully slow and may be too late. The underlying problem is the conflict of interests between the local people and the conservationists. The human population of Zakynthos has declined steadily over the last 40 years and is now about 30,000 (Figure 4a). Tourism is the main industry and, since the opening of an airport, has increased dramatically (Figure $4 b$ ). Built-up areas have expanded by 20 per cent since 1971. The local people have a respect for the turtles and do not harm them or take the eggs, but their respect does not extend to denying themselves a livelihood. Thanks to a good road network, Lagana beach has already been heavily developed and landowners at the other sites would like to see their beaches opened up to the tourist market. Indeed, a taverna was opened at Dafni in 1982, which, coupled with an associated speedboat firm could have spelt disaster for the turtles. In the event business was never good because the beach is virtually inaccessible except by sea.

Faced with such opposition it is not surprising that conservation of the turtles has not been a priority for the Ministry of the Environment. While the passing of the Ministerial Decision was a step in the right direction, the problems of implementation are great, yet the continued survival of the turtle population could depend on its success. Education can change the habits of the tourists and it is relatively easy to keep them off the beaches at night, but the local people are less easily persuaded. The restrictions placed on them by the Directive are quite severe and effectively deny those affected from making money from tourism, while their lucky neighbours may actually be encouraged to do so. The unfairness of the situation has led to considerable ill feeling and even some instances of violence. The only real answer to the problem is expropriation of the land and it is
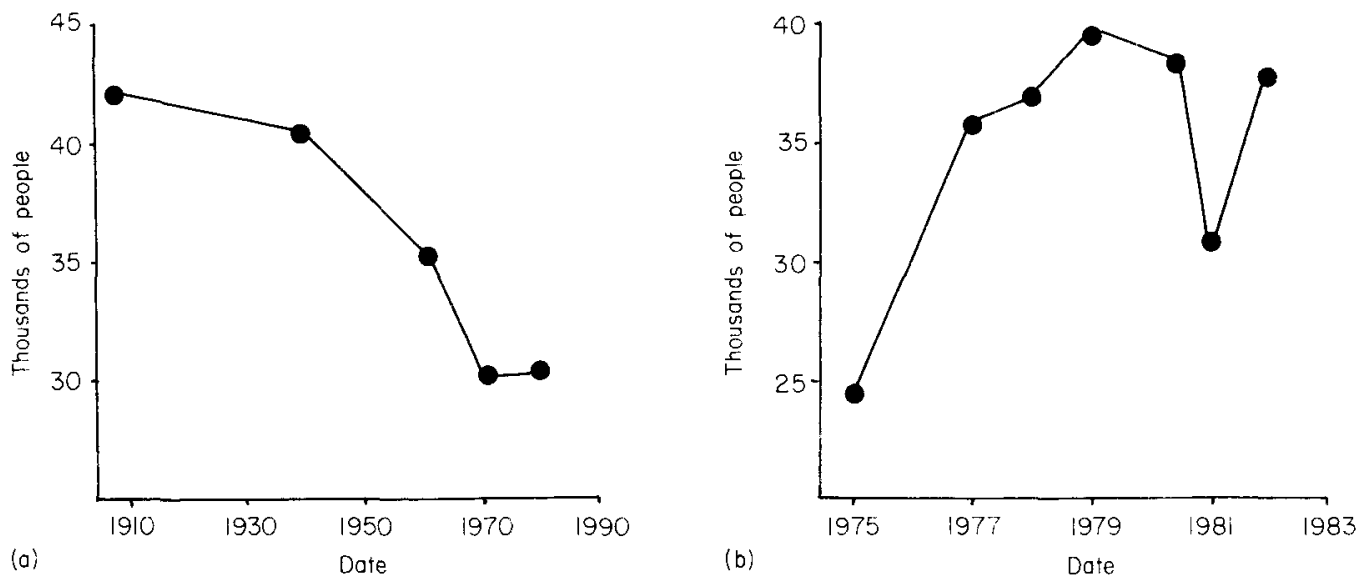

Figure 4. The population of Zakynthos: (a) local inhabitants; (b) number of tourists per season. 
encouraging to know that the government is considering this. At present, however, they have promised only $\$ 400,000$ to cover all costs. These include: the employment of guards to close the beaches at night; the placement of barriers across access points to keep cars off the dirt tracks leading to the less accessible beaches; the uprooting of trees on the beach at Kalamaki; and payment for expropriation of key sites at Sekania and Dafni.

It is too soon to tell whether the turtles have benefited from these efforts. Tourism was down in the 1987 season, probably because of poor facilities (Simon Lyster, pers. comm.). While this may seem beneficial, unfortunately the locals are blaming the decline on efforts to keep tourists away from the turtles and this may further alienate them from the cause. At the start of the season there appeared to be little attempt at official implementation of the Ministerial Decision, although things did improve later on. It is clear that enforcement must be improved in future seasons. Without the active involvement of the central government it is unlikely that the local political opposition will be resisted, and the result will be the loss of the turtles.

\section{Acknowledgments}

We are grateful to Mrs Lily Veniselos for supplying much useful information. Dr Simon Lyster of WWFUK kindly commented on the draft manuscript for us. We should like to thank the two anonymous referees for their valuable comments and suggestions.

\section{References}

Bustard, R. 1972. Sea Turtles. Collins, Glasgow.

Carr, A. and Ogren, L. 1960. The ecology and migrations of sea turtles, 4 . The green turtle in the Caribbean Sea. Bull. Amer. Mus. Nat. Hist. 121, 1-48.

Groombridge, B. 1982. Red Data Book. AmphibiaReptilia Pt. 2. Testudines, Crocodylia, Rhyncocephalia. IUCN, Switzerland.

Holme, N. A. and McIntyre, A. D. 1971. Methods for the Study of Marine Benthos. Blackwell Scientific Publications, Oxford.

Langton, T. 1987. Zakynthos: loggerhead protection enters critical phase. Herpetofauna News No. 7.
Mann. T. M. 1977. Impact of developed coastline on nesting and hatching sea turtles in Southeastern Florida. M. Sc. Dissertation, Florida Atlantic University.

Margaritoulis, D. 1982. Observations on loggerhead sea turtle Caretta caretta activity during three nesting seasons (1977-1979) in Zakynthos, Greece. Biol. Conserv. 24, 193-204.

McFarlane, R. W. 1963. Disorientation of loggerhead hatchlings by artificial road lighting. Copeia 1963, p. 153.

Mertens, R. U. and Wermuth, H. 1960. Die Amphibien und Reptilien Europas. Waldemar Kramer, Frankfurt am M.

Richardson, J. I. and Richardson, T. H. 1983. An experimental population model for the loggerhead sea turtle (Caretta caretta). In: Biology and Conservation of Sea Turtles (ed. A. K. Bjorndal), Smithsonian Institution Press, Washington DC.

Ruckdeschal, C. and Zug, G. R. 1982. Mortality of sea turtles Caretta caretta in coastal waters of Georgia. Biol. Conserv. 22, 5-9.

Sella, I. 1983. The turtles in the eastern Mediterranean; in danger of extinction. In: Biology and Conservation of Sea Turtles (ed. A. K. Bjorndal), Smithsonian Institution Press, Washington DC.

Sternberg, J. 1981. The worldwide distribution of sea turtle nesting beaches. Centre for Environmental Education, Washington, DC.

Sutherland, J. M. 1984. Report on the biology and conservation of the loggerhead turtle, Caretta caretta, from the Greek island of Zakynthos. Unpublished report to the World Wildlife Fund $\mathrm{UK}, 44 \mathrm{pp}$.

Lynda M. Warren. Cardiff Law School, University of Wales, College of Cardiff, P. O. Box 427, Cardiff CF1 IXD, UK.

Eleni Antonopoulou, School of Biotechnology, Polytechnic of Central London, 115 New Cavendish Street, London W1M 8JS, UK (Present address:Dionysou 52, Halandri, Athens 152 34, Greece).

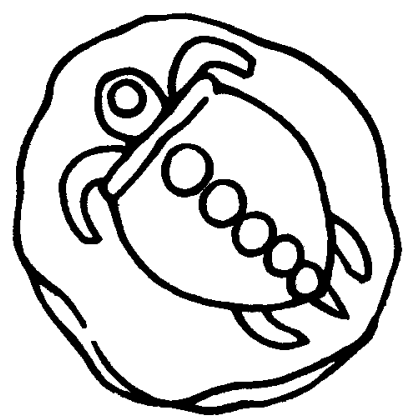

Logo of the Greek Sea Turtle Protection Society founded in 1983. 